\title{
THE ANALYSIS OF SOCIAL AND EMOTIONAL DEVELOPMENT OF MENTALLY DISABLED CHILDREN (MILD) ON GRADE 2 OF MUHAMMADIYAH BANGUNTAPAN PRIMARY SCHOOL YOGYAKARTA
}

\author{
Muhammad Shaleh Assingkily, Munganatul Khoeriyah, Khamim Zarkasih Putro \\ Universitas Islam Negeri Sunan Kalijaga Yogyakarta \\ E-mail: 18204080019@ student.uin-suka.ac.id, khoeriyahmunganatul@gmail.com, \\ hamimzarkasih@gmail.com
}

\begin{abstract}
Every child is unique, including a mentally disabled child. The potential for selfdevelopment in academic, social, and workability becomes a necessity for mild mentally disabled children. This study aims to analyze the social and emotional development of mild mentally disabled children in grade 2 of Muhammadiyah Banguntapan Primary School Yogyakarta, or usually called SD Muhammadiyah Banguntapan Yogyakarta. Two formulations of the problems of this research are (1) how the social-emotional development of mild mentally disabled children in grade 2 of SD Muhammadiyah Banguntapan Yogyakarta in the classroom and outside the classroom and (2) how the teacher's efforts in developing the child's social-emotional development. The research data were obtained through a qualitative approach with observation, interviews, and analysis of document studies of mild mentally disabled children in grade 2 of SD Muhammadiyah Banguntapan Yogyakarta. From this study, the results were obtained that the social-emotional development of mentally disabled children in the class was achieved in the form of caring, interactive, and displaying an attitude of confidence, while what was not achieved in the form of participation, communication, and teamwork abilities. Whereas outside the classroom, the attainment is in the form of empathy and what is not achieved in the form of solitude and self-ness (ego) and has not been able to control emotions when socializing. The efforts made by teachers in developing children's social-emotional attitudes, namely: asking children to apologize and admit their own mistakes, motivating, "bluffing", advising children, setting seating, and trying to help children.
\end{abstract}

\section{Keywords: Mild mentally disabled, Children, Social-emotional development, Primary School.}

\section{INTRODUCTION}

Mentally disabled children are God's gifts who are mandated to parents. However, people in Indonesia, in general, are claiming they usually regard children mentally disabled or better known as an idiot, it cannot be improved ability to think, even though already undergoing education in special schools. While mentally disabled children have unique potential, so they need special care. One of the treatments is the social-emotional development of mentally disabled children. 
The analysis of social-emotional development of children have naturally been discussed by previous researchers. The area which are discussed cover aspects of precedent, ${ }^{1}$ learning model, ${ }^{2}$ learning strategy, ${ }^{3}$ and how to respond to the achievement or unachievement of children's emotional social development. ${ }^{4}$ It is considered as necessary because each phase and stage of development, children should experience it optimally.

In general, primary schools accept students as children who will be educated, and they are responsible for their education at school by the teacher. Primary School of Muhammadiyah Banguntapan Yogyakarta indicates inclusivity values that should be familiarized to children since their primary age in which in the previous study light mentally category of the student was found on Grade 2 of Primary School. ${ }^{5}$ The student is MAM. He is usually educated and developed by an individual assistant teacher, Siti Zulaichah.

Based on the reasons and consideration of the need for the latest information about the characteristics of the development and development of social-emotional aspects of mentally disabled children in the real context at the elementary school level, this study examines the issue. The formulation of the problems that are the focus of this research discussion is: first, how the social-emotional development of mildly disabled children in class 2 SD Muhammadiyah Banguntapan Yogyakarta in the classroom and

1 Nurjannah, "Mengembangkan Kecerdasan Sosial Emosional Anak Usia Dini Melalui Keteladanan" HISBAH: Jurnal Bimbingan dan Konseling Dakwah Islam 14 (1), 2017: 50-61. http://ejournal.uin-suka.ac.id/dakwah/hisbah/article/viewFile/141-05/990. See: Asrizal dan Pipin Armita, "Pendidikan Islam Terhadap Anak Berkebutuhan Khusus" HIKMAH: Jurnal Pendidikan Islam 7 (1), 2018: 149-167. http://ojs.staituankutambusai.ac.id/index.php/hikmah/article/view/85/62.

2 Norma Yunaini, "Model Pembelajaran Tunagrahita: Studi Multisitus di SLB Negeri 1 Bantul dan SLB Negeri 2 Yogyakarta", Tesis, (Yogyakarta: Program Magister FITK UIN Sunan Kalijaga Yogyakarta, 2018). See: Intan Kumala Sari dan Darliana Sormin, "Metode Pembelajaran Pendidikan Agama Islam pada Anak Tunagrahita di SLB C Muzdalifah Medan" TAZKIR: Jurnal Penelitian Ilmuilmu Sosial dan Keislaman $5 \quad$ (1), 2019: $1-24 . \quad$ http://jurnal.iainpadangsidimpuan.ac.id/index.php/TZ/article/view/1596/1414.

${ }^{3}$ Oki Dermawan, "Strategi Pembelajaran Bagi Anak Berkebutuhan Khusus di SLB” Psympathic: $\begin{array}{llllll}\text { Jurnal Ilmiah } & \text { Psikologi } & 6 & (2), & \text { 2013: } & \text { 886-897. }\end{array}$ http://journal.uinsgd.ac.id/index.php/psy/article/view/2206/1536.

4 Muhammad Shaleh Assingkily dan Mikyal Hardiyati, "Analisis Perkembangan SosialEmosional Tercapai dan Tidak Tercapai Siswa Usia Dasar" Al-Aulad: Journal of Primary Education 2 (2), 2019: 19-31. http://journal.uinsgd.ac.id/index.php/al-aulad/article/view/5210/3016. See: Hikmah Risqi Awalia, "Studi Deskriptif Kemampuan Interaksi Sosial Anak Tunagrahita Ringan" Jurnal Pendidikan Khusus 9 (1), 2016: 1-16. https://jurnalmahasiswa.unesa.ac.id/index.php/jurnal-pendidikankhusus/article/view/17924/16332. $31^{\text {st }} 2019$. 
outside the classroom; and second how the teacher's efforts in developing the child's social-emotional.

\section{RESEARCH METHODS}

The research was focused on the analysis of the social-emotional development of a mentally disabled child at Muhammadiyah Banguntapan Primary School Yogyakarta. This empirical research tried to analyze mentally disabled children's social-emotional attitudes in and outside the classroom and effort, which was done by teachers in developing the mentally disabled child's social-emotional development. So, suitable approach research to the empirical fact (field research) is a qualitative approach. This research used in-depth interviews, observation, and documentation to collect data.

\section{RESULT AND DISCUSSION}

\section{Child's Self Identity}

MAM is the first child of Mr. SJ and Mrs. SN. He is a student of grade 2 of Muhammadiyah Banguntapan Primary School Yogyakarta.

\section{Table 1}

Student of Muhammadiyah Banguntapan Primary School who becomes the research object ${ }^{6}$

\begin{tabular}{ccccc}
\hline No. & Initial Name & \multicolumn{1}{c}{$\begin{array}{c}\text { Initial Name of } \\
\text { Parents }\end{array}$} & Place of Birth & Date of Birth \\
\hline 1. & MAM & SJ (Ayah) & Gunung Kidul & March, 25 $5^{\text {th }}$ \\
& & SN (Ibu) & & 2011 \\
\hline
\end{tabular}

When MAM was a little boy, he had the normal physical condition as friends at his age. However, catalepsy, which was suffered by him since he was a child caused his inability to walk. When his friends at the same age could walk, he could not. The result was obtained from the interview with MAM's mother:

"Tubuhnya MAM niku normal, mboten enten ingkang cacat. Riyin pas alit MAM sering kejang-kejang dados ndamel MAM teras-terasan anggadahi penyakit meniko. Naliko rencang seyuswone mpun saget mlapah nanging MAM dereng saget mlampah."7

\footnotetext{
${ }^{6}$ Document of Muhammadiyah Banguntapan Primary School, Student s' Data

${ }^{7}$ Interview with Mrs. SN (MAM's mother) on Friday, $16^{\text {th }}$ August 2019, at 08.13 A.M.
} 
"MAM's body was normal, and there was no disability. When he was a child, he has suffered from catalepsy until now. When his friends could walk, he could not."

According to the confirmation from the teacher who teaches him in class, Zakky is categorized as mild mentally retarded with IQ test result 67. His learning and potential spirit to "heal" highly support his potential development. ${ }^{8}$ Therefore, right social and emotional encouragement is crucial to support his development achievement.

\section{Social and Emotional Attitude of Children In and Outside the Classroom}

\section{In the Classroom}

MAM is a student who tends to be calm and happy to be alone. If he joins or studies cooperatively, he lacks confidence, so he needs the teacher's assistance. He shows his attention to his classroom mates. For example, when a friend forgets to bring an eraser and pencil, he is willing to lend his. However, he is a selective person, especially in selecting a seatmate. He feels comfortable to have a seatmate whose name is Shaki (Although Shaki wants to have a different seatmate because he feels uncomfortable). ${ }^{9}$

MAM has excellent communication and interaction with the seatmate in the classroom because he feels Shaki is his best friend. Sometimes he obeys and follows Shaki's suggestion. MAM's emotional feeling rarely appears if he interacts with Shaki. ${ }^{10}$

Based on the classroom observation result, it indicates that some categories of MAM's emotional-social attitude (mild mental retarder child) as a student of grade 2 Muhammadiyah Banguntapan Primary School Yogyakarta are achieved, and the others are not (see further on table 2).

\section{Outside the Classroom}

Outside the classroom, MAM indicates happiness to play with his friends. He can also ask and be asked to play together by both school friends or playmates at home.

It is shown in MAM's story on his experience at home:

${ }^{8}$ Based on the information from Siti Zulaichah, S.Pd., during the interview in from classroom of grade 2 at Muhammadiyah Primary School, and researcher's direct observation data on grade 2 of Muhammdiyah Banguntapan Primary School Yogyakarta.

${ }^{9}$ Based on the information from Siti Zulaichah, S.Pd., during the interview in teacher's room at Muhammadiyah Primary School Yogyakarta, Senin, August, 12 ${ }^{\text {nd }}$ 2019, at 11.14 A.M.

10 Observation at Muhammadiyah Banguntapan Primary School Yogyakarta, on Wednesday, August $14^{\text {th }} 2019$, at $11.02 \mathrm{~A}, \mathrm{M}$. 
"MAM was bicycling in front of house with friends, but one of MAM's friends fell from the bicycle. At that time, Zakky only saw Ms because has not able to help. Nevertheless, other friends of the bicycling group helped him." 11

When he meets his classmate at home (his neighbor), Izza, they greet each other and sometimes chat. Sometimes, when a friend bullies him, MAM prefers to be calm if he can control his emotions. If he cannot, he will get angry and wriggle cry.

"MAM also experiences unbalanced motoric balance. He often fell when he was walking or running. His walking tended to the left (unstable body) and dragged. When he was running, his feet are rather dragged on the land. It is proven with the tip of Zakhi's fingers are blister." 12

Based on the result of analysis of mild mentally disabled children's socialemotional development, MAM, it is obtained data analysis results inform the following Table 2 and Table 3:

Table 2

Result of Social Emotional Development Analysis in the Classroom

\begin{tabular}{|c|c|c|c|}
\hline No. & Attitude & Analysis Description Result & Remark \\
\hline 1. & $\begin{array}{l}\text { Care / } \\
\text { Attentive }\end{array}$ & $\begin{array}{l}\text { When a friend needs a pencil or eraser, MAM will } \\
\text { lend him/her although he is willing to do it } \\
\text { alternately. }\end{array}$ & Achieved \\
\hline 2. & $\begin{array}{l}\text { Participatio } \\
\mathrm{n}\end{array}$ & $\begin{array}{l}\text { MAM prefers to do everything by himself with an } \\
\text { assistance and instruction from teacher because he } \\
\text { lacks of confidence when working in group. }\end{array}$ & $\begin{array}{c}\text { Unachiev } \\
\text { ed }\end{array}$ \\
\hline 3. & $\begin{array}{l}\text { Communica } \\
\text { tion }\end{array}$ & $\begin{array}{l}\text { MAM's seatmate chooses to be alone, but } \\
\text { teacher manages the sitting position. MAM feels } \\
\text { comfortable to sit beside Shaki and does not want } \\
\text { to replace him. However, Shaki as his seatmate } \\
\text { wants to replace MAM for many times because he } \\
\text { feels uncomfortable with him ('ora penak e bu' } \\
\text { Shaki said). } \\
\text { MAM has good communication and interaction } \\
\text { with his seatmate. Because MAM feels that he is a } \\
\text { best friend. Sometimes it is easy for him to obey } \\
\text { and follow Shaki's suggestion. MAM's emotional } \\
\text { feeling rarely appears if interacting with Shaki. }\end{array}$ & $\begin{array}{l}\text { Unachiev } \\
\quad \text { ed }\end{array}$ \\
\hline 4. & Interactive & $\begin{array}{l}\text { He is not selective in playing with friends in the } \\
\text { classroom. He only selects his seatmate. }\end{array}$ & Achieved \\
\hline 5. & Teamwork & MAM always asks (it can said that he always & Unachiev \\
\hline
\end{tabular}

11 Interview with MAM (Mild mentally retarded child who is on grade 2 Muhammadiyah Banguntapan Primary School Yogyakarta), Friday, August $9^{\text {th }} 2019$ at 09.55 A.M.

${ }^{12}$ Interview with Siti Zulaichah, Teacher of Grade 2 of Muhammadiyah Banguntapan Primary School Yogyakarta, Friday, $1^{\text {st }}$ August 2019, at 08.30 A.M. 


\begin{tabular}{lclcc}
\hline No. & Attitude & \multicolumn{1}{c}{ Analysis Description Result } & Remark \\
\hline Competence & $\begin{array}{l}\text { asks even it is only a simple task). However, if he } \\
\text { does not have a chance to ask, he keeps silent and } \\
\text { wait for a friend asks and approaches him. } \\
\text { When MAM is bullied or offended with his } \\
\text { friends, he will speak rude. }\end{array}$ & \\
\hline 6. & $\begin{array}{l}\text { Presenting } \\
\text { Self- } \\
\text { Confidence }\end{array}$ & $\begin{array}{l}\text { MAM loves making friends on grade } 2 \text { and } \\
\text { interact confidently with them. }\end{array}$ & & \\
& &
\end{tabular}

Table 3

Result of Social-Emotional Development Analysis outside Classroom

\begin{tabular}{|c|c|c|c|}
\hline No. & Attitude & Analysis Description Method & Remark \\
\hline 1. & Empathy & $\begin{array}{l}\text { MAM likes playing with his friends. He can } \\
\text { also ask and be asked to play together by both } \\
\text { friends at school or house environment. }\end{array}$ & Achieved \\
\hline 2. & $\begin{array}{l}\text { Does not } \\
\text { indicate the } \\
\text { selfish attitude }\end{array}$ & $\begin{array}{l}\text { MAM keeps silent and lacks of self confidence } \\
\text { in suggesting play rule with his friends } \\
\text { (unselfish) but less confident. }\end{array}$ & $\begin{array}{c}\text { Unachieve } \\
d\end{array}$ \\
\hline 3. & $\begin{array}{l}\text { Able to } \\
\text { control } \\
\text { emotion when } \\
\text { playing and } \\
\text { interacting } \\
\text { with friends }\end{array}$ & $\begin{array}{l}\text { If his friends are fighting, he keep silent or } \\
\text { yells 'huuu.' When meeting Izza, his } \\
\text { schoolmate, at home (neighbor), they greet each } \\
\text { other and sometimes chat. } \\
\text { When a friend bullies him, MAM keeps } \\
\text { silent if he can control his emotion. If he cannot, } \\
\text { he will get angry and wriggle cry. }\end{array}$ & $\begin{array}{c}\text { Unachieve } \\
d\end{array}$ \\
\hline
\end{tabular}

\section{Teacher's Effort to Develop Social-Emotional of Mild Retarded Children}

Teacher of Grade 2 Muhammadiyah Primary School Banguntapan Yogyakarta, who often handles and even trains MAM's ability, a mild mentally retarded is Siti Zulaichah, S.Pd. In her daily life, Siti does many activities to train MAM. It is done by herself. There some other lesson teachers.

The following is Siti's statement on MAM.

"In my opinion, MAM should follow medical treatment. He should routinely do the routine occupation, minimum $2 x$ (twice) a week. However, because of the cost, it cannot be continued. It is regretted because MAM has a high potential to recover. This potential is seen in sports lesson."13

\footnotetext{
${ }^{13}$ Interview with Siti Zulaichah, Teacher of Grade 2 of Muhammadiyah Banguntapan Primary School Yogyakarta, Friday, August $1^{\text {st }} 2019$, at 08.30 A.M.
} 
Another result is obtained from Sports Teacher of Grade 2 at Muhammadyah Primary School Banguntapan, Dwi Hartana that said:

"So far, MAM follows all physical exercises (running, warming up and playing foot ball) with 'normal' classmate (as if his disability is not a problem). His spirit and motivation to play with non-special needs children peers in big classroom, brother." 14

"Observation which is performed at school indicates that MAM can maintain personal cleanliness such as pee, blow the nose, and defecate independently and certainly it is monitored by adult people." 15

MAM's social attitude at school also indicates proper treatment towards his friends. He wants to share what he has, such as snacks, food, and drinking water, if his friend asks for it. He often lends pencil color, eraser, and paper of his drawing book if his friend asks for it because he/she does not bring it. The attitude often changes as his emotional condition with his friend (his chosen friend). On the contrary, MAM's friend is willing to share food with and lend MAM pencil color. ${ }^{16}$

In particular condition, sometimes MAM is reluctant to lend his stuff (for example eraser) to his friend, as the information which is obtained from an interview with Siti Zulaichah as follow:

"When he did not have it, and he was forced and persuaded to borrow, he does not want it. He preferred to keep silent and stop his writing activity. He only borrowed from a friend he chooses. ${ }^{17}$

A condition which indicates MAM's social-emotional attitude during the training and development with Siti Zulaichah does undoubtedly not always run 'smoothly', there are difficulties she finds. The following is Siti Zulaichah's statement concerning the problem she feels:

"MAM often got angry and rampage, whereas it is caused by himself. For example, he bullied his friend and rampaged when his friend bullied him. Even he howled, wriggled, and fought his friend back. If it occurred, I held MAM

14 Interview with Dwi Hartana, S.Pd., Sport Teacher of Muhammadiyah Banguntapan Primary School Yogyakarta, Saturday, $2^{\text {nd }}$ August 2019 at 09.17 A.M.

15 Observation at Muhammadiyah Banguntapan Primary School Yogyakarta, Friday, $23^{\text {rd }}$ August 2019 at 10.15 A.M.

16 Observation at Muhammadiyah Banguntapan Primary School Yogyakarta, Monday, September $2^{\text {nd }} 2019$, at 02.30 P.M.

17 Observation at Muhammadiyah Banguntapan Primary School Yogyakarta, Monday, September $2^{\text {nd }} 2019$, at 02.30 P.M. 
strongly because he would pursue his friend until he got and beat that friend. After that, I asked him to sit down and calm him. Then I could only ask him. It is miraculously, he is never sad or something after that. He could continue his activities. Sometimes he would laugh as if nothing has happened. Everytime MAM starts bullying (which he considers it as a joke), I will ask him to apologize." 18

Siti is accustomed to it as she has trained and developed MAM directly. She stated that:

"At first I felt difficulty to calm him down. Even I was scared facing such conditions. He would not stop, although I prohibited him. He stopped and obeyed his homeroom teacher to whom he is scare of. Because I have been with him since grade 1, the fear of his anger has disappeared. In my opinion, another factor that made him refused to stop rampaging was because I intimidated him. If he did not want to be managed and obey me, I would never assist him anymore." 19

Other information as an effort which is done by Siti to MAM is training his social attitude as the following:

"Every time MAM brought food, and he would give it to me so I could take it. I managed his food. He gave me a package of 'sugus' candy. I told him to give candy to each friend. MAM said, yes. Without being managed by me, he would also voluntarily give his friends food to his friends." 20

MAM chooses his seatmate who is considered as his best friend. He will have attention to him and emotionally treat his best friend differently with other friends. MAM chooses Shaki as his best friend and will only sit with him.

Shaki is MAM's seatmate. Naturally, he does not want to sit beside MAM. As Shaki's explanation during the interview:

"Actually I want to move and sit with other friends, sir. But MAM gets angry and cries. He does want to sit separately with me, sir. My teacher asked me to be patient because Allah loves me. There will be a moment to sit in a group and change the seatmate with other friends." 21

\footnotetext{
${ }^{18}$ Interview with Siti Zulaichah, Teacher of Grade 2 of Muhammadiyah Banguntapan Primary School Yogyakarta, Firday $23^{\text {rd }}$ August 2019, at 09.40 A.M..

${ }^{19}$ Interview with Siti Zulaichah, Teacher of Grade 2 of Muhammadiyah Banguntapan Primary School Yogyakarta, Friday $30^{\text {th }}$ August 2019, at 07.40 A,M.

${ }^{20}$ Interview with Siti Zulaichah, Teacher of Grade 2 of Muhammadiyah Banguntapan Primary School Yogyakarta, September $4^{\text {th }} 2019$, at 11.34 A.M.

${ }^{21}$ Interview with Shaki Azaria Maulana (Friend of MAM the Mild mentally retarded child who is on grade 2 Muhammadiyah Banguntapan Primary School Yogyakarta), Friday, August $30^{\text {th }} 2019$ at 10.57 A.M.
} 
Also, in order to anticipate Shaki's uncomfort, Siti as the teacher tries to do group study in the classroom, so that she can manage students' position. Setting chairs in a group to make Shaki feels comfortable to sit beside MAM. ${ }^{22}$

In group work, MAM wants to participate although other friends often hesitate about him. MAM is not confident in his ability, so the teacher always gives and share teamwork portion, which is obtained to MAM. For example, a portion of grouping pictures and motivating the class with a compliment "wow, MAM is smart, awesome and can answer." 23

MAM can follow the flow of playing with his classmates. MAM can follow any game which is done by male students. If a conflict occurs, his friends always assist MAM and remind him of the rules of playing. For example, they cannot get angry when playing or bully each other (spit out a name). They cannot beat. The teacher also reminds that MAM is different. "MAM is different from you." She calls MAM as "a special child." It is expected to build understanding feeling if something happens or treat MAM as unique so that the other students are not jealous. ${ }^{24}$

Based on the psychological assessment, MAM's social attitude is not appropriate for his real age. Based on the social attitude, which is shown by MAM, his attitude is similar to the 5-year old child (Kindergarten student).

The action of training MAM's emotional attitude in practice has not been shown directly during the field observation ${ }^{25}$. The teacher shows verbal expression as advice. It is indicated with Siti's information as follow:

"We have not trained MAM's emotional. We do it by giving an understanding. "How do MAM call Ega?" Then he replied, "Gagak". "How is MAM called?" "Yakult," he replied. So it is a game, isn't it? MAM nods. If it is a game, do not get angry, okay? MAM nods. "Do you understand?" MAM nods again."26

\footnotetext{
${ }^{22}$ Interview with Siti Zulaichah, Teacher of Grade 2 of Muhammadiyah Banguntapan Primary School Yogyakarta, Friday $30^{\text {th }}$ August 2019, at 09.57 A,M.

${ }^{23}$ Observation at Muhammadiyah Banguntapan Primary School Yogyakarta, Friday $30^{\text {th }}$ August 2019, at 08.48 A.M and Interview with Siti Zulaichah, Teacher of Grade 2 of Muhammadiyah Banguntapan Primary School Yogyakarta, Friday $30^{\text {th }}$ August 2019, at 09.57 A.M.

${ }_{24}$ Observation at Muhammadiyah Banguntapan Primary School Yogyakarta, Friday $30^{\text {th }}$ August 2019, at 08.48 A.M.

${ }^{25}$ Observation at Muhammadiyah Banguntapan Primary School Yogyakarta, Friday $30^{\text {th }}$ August 2019.

${ }^{26}$ Interview with Siti Zulaichah, Teacher of Grade 2 of Muhammadiyah Banguntapan Primary School Yogyakarta, Friday $30^{\text {th }}$ August 2019, at 02.10 P.M.
} 
The teachers acknowledge that of 37 students of grade 2, only MAM who gets special treatment. For example, when he should be asked to study outside by Mrs.Siti as the individual assistant teacher or in Indonesia is called Guru Pembimbing Khusus (GPK). She also performs cognitive development assessments on children with special needs. Siti does more development in portion class for children with special needs than normal children. The instruction is more detail to MAM.

Table 4

The Result of Teacher's Effort Analysis

\begin{tabular}{|c|c|c|c|}
\hline No. & $\begin{array}{c}\text { Teacher's } \\
\text { effort }\end{array}$ & Analysis Description Result & Remark \\
\hline 1. & $\begin{array}{lr}\text { Ask } & \text { to } \\
\text { apologize } & \text { and } \\
\text { admit } & \text { a } \\
\text { mistake. } & \end{array}$ & $\begin{array}{l}\text { MAM often gets angry and rampages. } \\
\text { Whereas MAM himself starts the problem. } \\
\text { He bullies his friend and rampages when his } \\
\text { friend bullies back. He even roars, wriggles, } \\
\text { and fights back. } \\
\text { When MAM starts it (he considers it as a } \\
\text { joke), I asks him to apologize." }\end{array}$ & $\begin{array}{l}\text { Controlling } \\
\text { children's ego }\end{array}$ \\
\hline 2. & Motivating & $\begin{array}{l}\text { MAM follows all physical exercises } \\
\text { (running, warming up and playing football) } \\
\text { with his 'normal' classmates (as if his } \\
\text { disability is not a problem). His spirit and } \\
\text { motivation to play with his peers in a big } \\
\text { classroom and he can play with typical } \\
\text { students who are not children with needs } \\
\text { (although it depends on an adult's } \\
\text { direction). }\end{array}$ & $\begin{array}{c}\text { Stimulating } \\
\text { children's } \\
\text { brave attitude } \\
\text { and mentality. }\end{array}$ \\
\hline 3. & Bullying & $\begin{array}{l}\text { At first, I felt difficulty to calm him. Even I } \\
\text { was scared facing such conditions. He } \\
\text { would not stop, although he was prohibited } \\
\text { by being. He stopped and obeyed his } \\
\text { homeroom teacher to whom he is scare of. } \\
\text { Because I have been with him since grade } \\
1 \text {, the fear of his anger has disappeared. In } \\
\text { my opinion, another factor that made him } \\
\text { refused to stop rampaging was because I } \\
\text { intimidated him. If he did not want to be } \\
\text { managed and obey me, I would never assist } \\
\text { him anymore. }\end{array}$ & $\begin{array}{l}\text { Embedding a } \\
\text { sense of } \\
\text { compliance on } \\
\text { children and } \\
\text { protective step } \\
\text { on their } \\
\text { proactive } \\
\text { activities to be } \\
\text { developed. }\end{array}$ \\
\hline 4. & Advising & $\begin{array}{l}\text { "We have not trained MAM's emotional. } \\
\text { We do it by giving an understanding. "How } \\
\text { do MAM call Ega?" Then he replied, } \\
\text { "Gagak". "How is MAM called?" } \\
\text { "Yakult", he replied. So it is a game, isn't }\end{array}$ & $\begin{array}{l}\text { Guiding } \\
\text { children's } \\
\text { emotional and } \\
\text { social state to a } \\
\text { good direction. }\end{array}$ \\
\hline
\end{tabular}




\begin{tabular}{|c|c|c|c|}
\hline No. & $\begin{array}{c}\text { Teacher's } \\
\text { effort }\end{array}$ & Analysis Description Result & Remark \\
\hline & & $\begin{array}{l}\text { it? MAM nods. If it is a game, don't get } \\
\text { angry, okay? MAM nods. "Do you } \\
\text { undertand?" MAM nods again }\end{array}$ & \\
\hline 5. & Managing & $\begin{array}{l}\text { "Every time MAM brought food, he would } \\
\text { give it to me so I could take it. I managed } \\
\text { his food. He gave me a package of "sugus' } \\
\text { candy. I told him to give candy to each } \\
\text { friend. MAM said, yes. Without being } \\
\text { managed by me, he would also voluntarily } \\
\text { give his friends food to his friends." }\end{array}$ & $\begin{array}{l}\text { Adapt } \\
\text { children's } \\
\text { orderly } \\
\text { attitude. }\end{array}$ \\
\hline 6. & Setting chairs & $\begin{array}{l}\text { in order to anticipate Shaki's uncomfort, } \\
\text { Siti, as the teacher tries to do group study in } \\
\text { the classroom so that she can manage the } \\
\text { students' position. Setting chairs in a group } \\
\text { to make Shaki feels comfortable to sit } \\
\text { beside MAM. }\end{array}$ & $\begin{array}{l}\text { Make up } \\
\text { children's } \\
\text { 'social- } \\
\text { emotional' } \\
\text { state on making } \\
\text { a friend. }\end{array}$ \\
\hline 7. & $\begin{array}{l}\text { Make children } \\
\text { independent. }\end{array}$ & $\begin{array}{l}\text { The observation which is performed at } \\
\text { school indicates that MAM is able to } \\
\text { maintain personal cleanliness such as } \\
\text { pee, blow the nose, and defecate } \\
\text { independently and indeed it is monitored by } \\
\text { adult people }\end{array}$ & $\begin{array}{l}\text { Allow the } \\
\text { children to be } \\
\text { creative and } \\
\text { responsible for } \\
\text { an adult's } \\
\text { assistance. }\end{array}$ \\
\hline
\end{tabular}

\section{Social-Emotional Development of Mentally Disbaled Children}

Social-emotional development is a response (reaction on stimulus) of children to understand other people in interacting (socializing). ${ }^{27}$ It is intended so that children are directed to be ready to receive differences within themselves and other people around them, whether it is the physical, attitude or egocentric of every individual.

Mentally disabled children are individuals who have potential and uniqueness. So characteristics that are presented daily become a uniqueness when interacting with other people. In order to find out the clarifications of mild, moderate and severe mentally retardation Binet and Weschler's scale is utilized as follows: ${ }^{28}$

Table 5

Clarifications of Mentally Retarded Children based on Retardation Level

\begin{tabular}{ccc}
\hline \multirow{2}{*}{ Retardation Level } & \multicolumn{2}{c}{ IQ } \\
\cline { 2 - 3 } & Stanford Binet & Weschler's Scale \\
\hline Mild & $68-52$ & $69-55$ \\
\hline Moderate & $51-36$ & $54-40$ \\
\hline
\end{tabular}

${ }^{27}$ Imam Musbikin, Ku Didik Anakku dengan Bahagia, (Yogyakarta: Mitra Pustaka, 2003).

${ }^{28}$ Sutjihati Somantri, Psikologi Anak Luar Biasa, (Bandung: PT Refika Aditama, 2012), p. 180. 


\begin{tabular}{ccc}
\hline \multirow{2}{*}{ Retardation Level } & \multicolumn{2}{c}{ IQ } \\
\cline { 2 - 3 } & Stanford Binet & Weschler's Scale \\
\hline Severe & $32-90$ & $39-25$ \\
\hline Profound & $>19$ & $>24$ \\
\hline
\end{tabular}

Table 5 provides information that, according to Standford Binet, mild category covers IQ of 68-52, and according to Weschler's scale, it is 69-55. In this case, MAM, as a student whose social-emotional development is analyzed based on the test result by the school in cooperation with psychology, indicates that MAM is categorized as mild mentally disabled category. ${ }^{29}$

Mentally disabled children find difficulty in comprehending complex information. ${ }^{30}$ Besides, they also experience difficulty in making a generalization when teacher gives an activity instruction. ${ }^{31}$ Therefore, special treatment should be done by the teacher or mentors in educating and directing mentally disabled children's potential.

According to Montessori, children's education should be relevant to their development stages and emphasize the importance of concentration, initiative development, and learning condition which provide a space for students to get personal achievement feeling. ${ }^{32}$ Therefore, both standard and mentally disabled children will undergo the developmental phases well. So, environmental support is required to assist the children in achieving the phases.

The understanding of the achievement effort of each phase on mentally disabled children, such as recognizing the characteristics of mentally disabled children's social and emotional support. ${ }^{33}$ Which is: the social aspect of mentally disabled children who experience slowness. Therefore, social support is supported to trigger development.

${ }^{29}$ Document (confidential) of IQ test result of MAM, student of grade 2 of Muhammadiyah Banguntapan Yogyakarta, by Intan Kusuma Wardhani, M.Psi, Psikolog (as Psychologgist Supervisor) dated in Yogyakarta, $15^{\text {th }}$ October 2018.

${ }^{30}$ Sutjihati Somantri, Psikologi Anak Luar Biasa, (Bandung: PT Refika Aditama, 2012), p. 111112.

31 Davit, et.al, Principles and Methods of Adapted Physical Education and Recreation, (America, New York: The Asia Foundation, 2005), p. 378.

${ }^{32}$ Maria Montessori, Montessori Method, terj. Gerald Lee Gutek, (Yogyakarta: Pustaka Pelajar, 2013), p. 78.

${ }^{33}$ Dinie Rantri Desiningrum, Psikologi Anak Berkebutuhan Khusus, (Yogyakarta: Psikosain, 2016), p. 17-18. 


\section{The Effort of Developing Mentally Disabled Children's Social and Emotional} (Mild)

In general, mild mentally disabled children are seen as healthy children who do not experience physical disability. ${ }^{34}$ It is also shown by the research object which acts and behaves normally. However, he needs social-emotional support to maintain his social interaction stability.

Furthermore, according to Aqila, the cause of mental retardation is anomaly genetic or chromosome. It is an infectious disease, especially in the first trimester, because the infant has not had an immune system, and it is a critical moment of brain development. Accident of suffering from trauma on the part of the head, premature baby (the baby who is delivered less than 9 months), dangerous chemical substance, poisoning on mother affect the infact or other thing inhaled by the infant. ${ }^{35}$

The cause is also experienced by the research object, MAM, in which he experiences the same thing but the category is mild. Furthermore, as a child who is diagnosed as mentally retarded, he has academic obstacles and incompetence in social interaction. ${ }^{36}$ Norma writes the same thing in her thesis that mentally disabled children have intellectuality but still have a potential that can be developed as their capacity. ${ }^{37}$ The point entry, which is intended by Norma, is an opportunity of developing mentally disabled children social-emotional.

According to Virgil and Ward, low achievement students of mentally disabled children needs more learning and individual assistance. Their teaching-learning processability is more focused on physical or over behavior. ${ }^{38}$ Special treatment towards mentally disabled children will increase their spirit that every child is unique.

Based on the information, it is understood that mentally disabled children are special with their uniqueness. Therefore, spirit and development spirit should be optimized to mentally retarded children so that their 'weakness' becomes self-

\footnotetext{
${ }^{34}$ Norma Yunaini, "Model Pembelajaran Tunagrahita: Studi Multisitus di SLB Negeri 1 Bantul dan SLB Negeri 2 Yogyakarta", Tesis, (Yogyakarta: Program Magister FITK UIN Sunan Kalijaga Yogyakarta, 2018), p. 49.

${ }^{35}$ Aqila Smart, Anak Cacat Bukan Kiamat, (Yogyakarta: Kata Hati, 2010), p. 52-53.

36 Geniofam, Mengasuh dan Mensukseskan Anak Berkebutuhan Khusus, (Yogyakarta: Gerai Ilmu, 2010), p. 24.

${ }^{37}$ Norma Yunaini, "Model Pembelajaran Tunagrahita: Studi Multisitus di SLB Negeri 1 Bantul dan SLB Negeri 2 Yogyakarta", Tesis, (Yogyakarta: Program Magister FITK UIN Sunan Kalijaga Yogyakarta, 2018), p. 49.

${ }^{38}$ Bandi Delphie, Pembelajaran Anak Tunagrahita, (Bandung: Refika Aditama, 2010), p. 57.
} 
motivation to improve the potential they have, including social-ecmotional development.

\section{CONCLUSIONS}

The research result indicates that social-emotional development of mild mentally disabled students at Muhammadiyah Banguntapan Primary School Yogyakarta in the classroom is divided into two: achieved and unachieved. The achived is in forms of attention/concern, interactive, and self-confidence. Unachieved is in forms of aloofness (has not participated), incommunicative, and does not indicate teamwork in the group. The outside classroom is divided into achieved, which is empathy attitude, and unachieved, which is egoism and inability to control emotion when socializing. Efforts that are performed by teachers in developing children's social-emotional attitudes such as apologize and acknowledge their mistake, motivate, "browbeat", advice children, set the chairs, and try to make children independent.

\section{REFERENCES}

Asrizal dan Pipin Armita, "Pendidikan Islam Terhadap Anak Berkebutuhan Khusus" HIKMAH: Jurnal Pendidikan Islam 7 (1), 2018: 149-167. http://ojs.staituankutambusai.ac.id/index.php/hikmah/article/view/85.

Assingkily, Muhammad Shaleh dan Mikyal Hardiyati. (2019). "Analisis Perkembangan Sosial-Emosional Tercapai dan Tidak Tercapai Siswa Usia Dasar" Al-Aulad: Journal of Primary Education 2 (2): 19-31. http://journal.uinsgd.ac.id/index.php/alaulad/article/view/5210/3016.

http://ojs.staituankutambusai.ac.id/index.php/hikmah/article/view/85/62.

Awalia, Hikmah Risqi. (2016). "Studi Deskriptif Kemampuan Interaksi Sosial Anak Tunagrahita Ringan" Jurnal Pendidikan Khusus 9 (1): 1-16. https://jurnalmahasiswa.unesa.ac.id/index.php/jurnal-pendidikankhusus/article/view/17924/16332.

Davit, et.al. (2005). Principles and Methods of Adapted Physical Education and Recreation, (America, New York: The Asia Foundation).

Delphie, Bandi. (2010). Pembelajaran Anak Tunagrahita, (Bandung: Refika Aditama).

Dermawan, Oki. (2013). "Strategi Pembelajaran Bagi Anak Berkebutuhan Khusus di SLB” Psympathic: Jurnal Ilmiah Psikologi $6 \quad$ (2): 886-897. http://journal.uinsgd.ac.id/index.php/psy/article/view/2206/1536.

Desiningrum, Dinie Rantri. (2016). Psikologi Anak Berkebutuhan Khusus, (Yogyakarta: Psikosain).

Geniofam. (2010). Mengasuh dan Mensukseskan Anak Berkebutuhan Khusus, (Yogyakarta: Gerai Ilmu). 
Montessori, Maria. (2013). Montessori Method, terj. Gerald Lee Gutek, (Yogyakarta: Pustaka Pelajar).

Musbikin, Imam. (2003). Ku Didik Anakku dengan Bahagia, (Yogyakarta: Mitra Pustaka).

Nurjannah. (2017). "Mengembangkan Kecerdasan Sosial Emosional Anak Usia Dini Melalui Keteladanan" HISBAH: Jurnal Bimbingan dan Konseling Dakwah Islam 14 (1): 50-61. http://ejournal.uin-suka.ac.id/dakwah/hisbah/article/viewFile/14105/990.

Sari, Intan Kumala dan Darliana Sormin. (2019). "Metode Pembelajaran Pendidikan Agama Islam pada Anak Tunagrahita di SLB C Muzdalifah Medan" TAZKIR: Jurnal Penelitian Ilmu-ilmu Sosial dan Keislaman 5 (1): 1-24. http://jurnal.iainpadangsidimpuan.ac.id/index.php/TZ/article/view/1596/1414.

Smart, Aqila. (2010). Anak Cacat Bukan Kiamat, (Yogyakarta: Kata Hati).

Yunaini, Norma. (2018). "Model Pembelajaran Tunagrahita: Studi Multisitus di SLB Negeri 1 Bantul dan SLB Negeri 2 Yogyakarta”, Tesis, (Yogyakarta: Program Magister FITK UIN Sunan Kalijaga Yogyakarta). 
The Analysis of Social and Emotional Deveopment of Mentally Retarded Children...

AL-BIDAYAH, Volume XI, Number 2, December 2019| 279 